\section{Insights into the applicability of the $X$-Ray phase quantification supported by SEM for the rock-forming silicates minerals in the basaltic lava flows}

IRINA M. GEMBITSKAYA - Saint Petersburg Mining University, Russian Federation - gembitckaia_im@pers.spmi.ru

ELENA L. KOTOVA - Saint-Petersburg Mining University, Russian Federation - kotova_el@pers.spmi.ru ILNUR A. ABDRAKHMANOV - Saint-Petersburg Mining University,

Russian Federation - ilnur_01_95@mail.ru

EMESE KUROVICS - Institute of Ceramics and Polymer Engineering, University of Miskolc, Hungary = fememese@uni-miskolc.hu

LÁszLó A. GÖMZE - Institute of Ceramics and Polymer Engineering, University of Miskolc, IGREX Engineering Service Ltd, Hungary and Tomsk State University, Russia - femgomze@uni-miskolc.hu Érkezett: 2020. 06. 30. - Received: 30. 06. 2020. - https://doi.org/10.14382/epitoanyag-jsbcm.2020.29

\section{Abstract}

The authors present their results obtained from the study of the magmatic rock-forming mineral phase-relations. In the study a number of standard and modern instruments were used for sample analyses. These include the X-Ray Diffraction, Scanning Electron Microscopy, X-Ray microprobe analysis and laser-granulometry analytic method. A combination of these instruments is considered very robust in the study of magmatic mineral-phases. The dataset obtained through the use of X-Ray Diffraction in combination with a corrected calibration on the mono-mineral fractions plays a critical role in comparing series of volcanic basalts. This approach was chosen for comparison studies of the volcanics due to its optical precision in determining modes and petrographic characteristics of the basaltic rocks. This study has used basaltic rocks from the modern volcanic eruptions of the Tolbachik region in the Russian Federation. Studies of other additional basaltic rocks were conducted from 10 samples which represents the Etna eruption which occurred in 2001. This enabled us to constrain the diversity in the nature of basaltic rocks of these two events.

Key words: basaltic lava flows, Etna, SEM, Tolbachik, X-Ray Diffraction

Kulcsszavak: bazaltos lávafolyások, Etna, SEM, Tolbachik, röntgendiffrakció
Irina M. GEMBITSKAYA

Is a Leading Researcher of Saint Petersburg Mining university. Author and co-author of more than 90 articles.

Elena L. KOTOVA is a Scientific director of the Mining museum of the Saint-Petersburg Mining university. Author and co-author of chapter in book, 1 patent and 32 articles. The member of the Russian Mineralogical Society, Oil and gas historica Society of Russia.

IInur A. ABDRAKHMANOV

Is a Postgraduate Student department of Mineralogy. Author and co-author 2 articles. The member of the Russian Mineralogical Society.

Emese KUROVICS is graduated from the University of Miskolo, Department of Ceramics and Silicate Engineering as a material engineer, where she continues he study as PhD student under supervision of Prof. L. A. Gömze.

László A. GÖMZE

is establisher and professor of the Department of Ceramics and Silicate Engineering in the University of Miskolc, Hungary. He is author or co-author of 2 patents, 6 books and more than 300 scientific papers

\section{Introduction}

The Tolbachikvolcanic event represents one of the few volcanic events which erupted the northern section of the Russian in the early Mesozoic period. One of the key features of basaltic melts is its micro-heterogeneous structure. Its transformation is the basis for different mobility of melt components, the behavior of volatiles, and process of polymerization and structuralchemical peculiarities of the silicates crystals. Methods of study of phase transformations are shown in [1-5]. This paper studies the phase-relations of the recent basaltic eruptions and intends to provide a comprehensive approach that combines macro-(Xray diffraction) and micro-/nano- (SEM) exploratory methods for spatial-temporal reconstruction of pre-eruptive dynamics. Based on the early study of rhyolites which was pioneered by Tatlock [6], the XRD application in quantifying mineral phases of these and other rock types has proven to be robust. These included the study of granites, volcaniclastic inputs into marine sediments, mudstones and carbonate rocks $[7,8]$.

The application of these methods involves the assessment of quantitative ratios between minerals and their fine features. Our study further compares the phase composition of samples with different quenching rates (degree of crystallinity): scoria, volcanic bombs, surface crusts or thin lava plates, lava, selected in a liquid state and hardened in air or water and lava, and those which were slowly cooled in the stream which shows a diverse phase-relation with similar chemistry.

The Rietveld method which was proposed by H.M Rietveld was applied herein to determine the main phase-proportions: olivine, pyroxene, plagioclase and volcanic glasses from 70 basaltic samples of the Tolbachick volcanic vent.

The Rietveld method is a widely accepted method due to its whole-pattern fitting approach instead of singlepeak analysis. The main advantage is that it can minimize or eliminate the errors arising from preferred orientation, particle statistics, microabsorption, peaks overlapping, and detection of amorphous phase and trace phases. Various amount of glass and crystals with broad isomorphism requires a different approximation [9]. The main conclusion was that, if amorphous material is present, quantitative results could not be obtained directly. The current study is devoted to similar basalt ranges with the smaller amount of olivines. The task requires mechanism of finding a log-linear response the diffractions maximums intensities to phase concentration and the sample-preparation process optimality (various grinding, pressing, mounting). 


\section{Geological setting}

Tolbachik is situated within the central Kamchatka depression, forming part of the Kluchevskoy group of volcanoes, the most active-volcanic vent in the Kamchatka arc. it encompasses the southern part of the Klyuchevskaya Volcanic Group, which is located within the Central Kamchatka Depression. The group is well-known to be one of the most productive and diverse subduction-related volcanic area on Earth with compositions of the erupting magmas ranging from basalt to dacite [10]. The volcanism of the group is driven by the subduction of the Pacific Plate under the Okhotsk microplate with an average convergence rate of $9 \mathrm{~cm} / \mathrm{yr}$. The unusually high rate of magmatic production is likely related to both great subduction rates and the proximity of the group to the corner of the Pacific Plate. Tolbachik is a comparatively well-studied volcanic complex in central Kamchatka. Early studies which were conducted in the complex dates back to the 18th century.

Piip [10] made a comprehensive study on the general geological features of the volcano and its eruption. His study covered the aspects of various basaltic melts. A large volume of geological, geochemical, and geophysical data was also collected during the 1975/1976 volcanic eruption famously known as 'The Great Tolbachik Fissure Eruption' [11].

The ASI shows the structural-chemical behaviour of the melt components as the molecular relationships $\mathrm{Al}_{2} \mathrm{O}_{3}(\mathrm{Al}$ in tetrahedral position as $\mathrm{Si}$ ) to net-forming cations (usually the alkaline and alkaline earth elements) $\mathrm{ASI}=\mathrm{Al}_{2} \mathrm{O}_{3} /\left(\mathrm{Na}_{2} \mathrm{O}+\mathrm{K}_{2} \mathrm{O}+\mathrm{CaO}\right)$. The Tolbachik volcanic series primarily comprises of two rock types: middle- $\mathrm{K}$, high-Mg (Mg/Al: 2,1; ASI: 0,45) basalts and high-K, high-Al (Mg/Al: 0,45; ASI: 0.8) basalts. The two basaltic series are composed of different major element concentrations with the greatest variation observed in $\mathrm{Mg}$ and $\mathrm{Al}$ contents. General regularities of changes in the chemical composition of the fissure eruptions in the Tolbachik zone are: the two extreme types of basalts which differ primarily in the content of $\mathrm{Mg}$ and Al. Besides that $\mathrm{Ni}, \mathrm{Co}, \mathrm{Cr}$ behaves like $\mathrm{Mg}$ and P, Ti, Na, K, Rb, Li like Al.

The high-Mg basalt was erupted during the 1941 activity, both types as well as the intermediate were erupted in the 1975-76, the high-Al basalt was erupted during the 2012-2013. The high-Al basalts were volumetrically dominant during the Holocene and comprise of more than $90 \%$ of the erupted material in Tolbachik volcanic zone. The main rock-forming minerals in all the volcanic lavas along the fault zone constituted of $\mathrm{Ol}, \mathrm{Cpx}$ and $\mathrm{Pl}$.

The basalts and intermediate rock types are predominantly characterized by isomorphic phases: $\mathrm{Ol}$ varies from $\mathrm{Fo}_{83-90}$, $\mathrm{Cpx}$ is diopside, diopsidic augite, augite with $\mathrm{Mg}_{66-88}$, and $\mathrm{Pl}$ is labradorite with $\mathrm{An}_{80-44}$.

\section{Sampling}

The rock materials of the 3 volcanic eruptions which occurred in Tolbachik area around 1941, 1975-1976, 2012-2013 were sampled. The erupted materials were sampled from the lava flows, volcanic bombs and, where possible, from scoria. The lapilli and bombs were collected, and a precautionary measure was taken into account during the sampling; where early pyroclastic materials were chosen in areas which are free from contamination by recent eruption.
Lavas were sampled in line with date and duration of their outpouring as well as the maps of lava fields showing the 1941, 1975-1976 and 2012-2013 flow units [10, 11]. The GPS coordinate database (IVS FEB RAS, Kamchatka) was of great assistance during the sampling of the 2012-2013 volcanic event. These events indicate similar features and spread along the same linear fault zone, although with variable intensity, duration, and various stages of differentiation [12]. The samples were collected along the lava flows from intermediate parts of lava flows using a sampling grid of approximately $200-400 \mathrm{~m}$ between points. Where possible, samples were taken from the basal zone (near bottom), from lava core and near the upper lava crust. Some of the samples: 6SBliq, M1912, M2512 were collected in a liquid state, the water or air quenched. Most of samples were collected after the lava had naturally cooled.

To test the approach applicability to basaltic products of other volcanoes, ten samples were collected from 2001 Etna lava flows (ASI: $0,55-0,6 ; \mathrm{Mg} / \mathrm{Al}: 1,05-0,75$ ). They were chosen because their quantification in optical mode had been previously studied by [13]. By the same token, various ranges of basaltic compositions have been encompassed.

\section{Sample preparation procedures}

Many mistakes can be minimized by adhering to proper sample preparation procedures, particularly in ensuring homogeneity of powder composition and grains sizes. To get optimum results these conditions were necessary: totally homogeneity over a range of $1 \mu \mathrm{m}$ (range), constant particles size, and absence of preferred orientation (texture), and also the lattice strain. The preparation of the suitable powders was done after choosing an optimal particles size. The rock powder was prepared using a five-minute grind in vibration mill Retsch Mixer Mill MM301 with $\mathrm{ZrO}_{2}$ ball and further grind in agate mortar to reach range of the particle's sizes from 1 to 5 $\mu \mathrm{m}$. The grinding time was chosen in experimental procedure, including measurements of grains sizes (Fig. 1b) and intensities of analytical X-ray peaks (Fig. 1c, 1d) ten minutes via (Fig. 1a). The optimal grinding time in agate mortar was $35 \mathrm{~min}$. The powders were examined by using SEM and the laser scattering particle size distribution analyzer Horiba LA960.
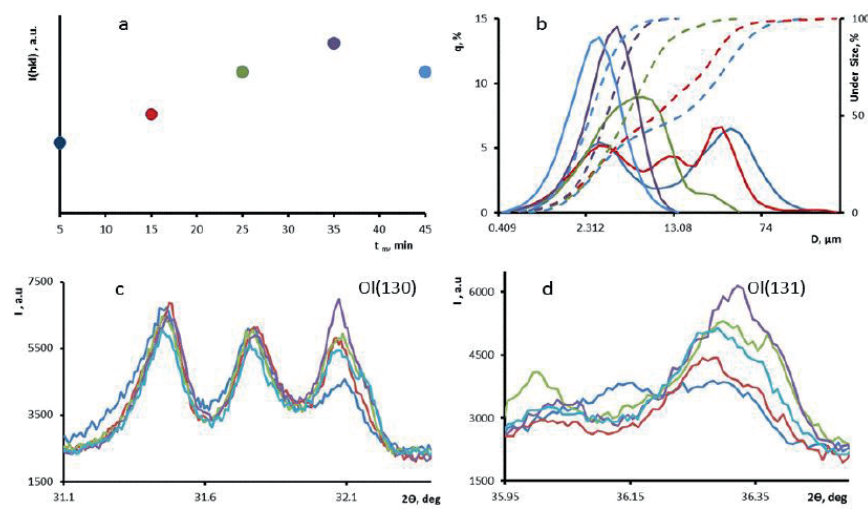

1. ábra A porrészecskék optimális méretének meghatározása a mintadarabon, minimális olivin-tartalommal

Fig. 1 Powder particles optimal size determination on the specimen with min olivine content 


\section{Analytical procedures}

The prepared lava samples and scoria were analyzed using X-ray diffractometer XRD6000 and processed under software control. $\mathrm{X}$-ray powder diffraction data was provided with diffractometer, with $\mathrm{Cu}$ Ka radiation and Ni filter. An amount of 5 wt.\% reference germanium standard material was added to the powder to calculate exactly the set of dhkl. Spectra were taken in the $2 \mathrm{~h}$-range 5-70, using $35 \mathrm{kV}, 45 \mathrm{~mA}$, speed $0.015 \mathrm{deg} / \mathrm{min}$, pitch 0.008 deg., present time $32 \mathrm{sec}$ a stepsize of 0.02 , a counting time of $5 \mathrm{~s}$ per step, divergence and antiscatter slits of 1 and receiving slit of $0.2 \mathrm{~mm}$.

The powdered samples were loaded on a sample holder by mixing thoroughly with ethanol. At first the two different cuvettes were used with front or side loading the powder to examine influence of grain orientations, and then lots of sub-samples (3-5pieces) were prepared and measured in order to arrive at a result which is indeed representative for the variable mineral composition. Analytical steps included: the measurement ranges being chosen, checked or refined for every new suit of samples; checking the stability of the X-ray generation; choosing scan speed 0.5 degree/min for common measurements and 0.03 degree/min for the olivine peaks (130), (131) and for the Cpx peaks (610), (131). The XRD peaks profiles varied according to glass ratio, grains sizes, isomorphism, macrostrains, and transformations of the minerals. Every sample measurement was repeated 3 times to check reproducibility. We applied mixtures from monomineral fractions (by washing of the crystals from the glass, using a special technique of HF flushing) and volcanic glass for calibrations. They were examined by using SEM and the laser scattering particle size distribution analyzer Horiba LA960 before using them as reference standards. It is well known, that the laser particle size analyzer doesn't measure about $5 \%$ smallest grains as well as $5 \%$ the biggest grains and doesn't notice complicated shape of particles. In this case a SEM provides quickly to determine what kind of problem does arise, if the sample is not ideal. It's very convenient to do the control of powder and specimen in SEM with COMPO signal and in low vac mode.

The powders of $\mathrm{Ol}, \mathrm{Px}, \mathrm{Pl}$ and glass were weighed, with a designed mass ratio of 10:30:40:20; 5:20:55:20; 0:40:40:20; $0: 35: 55: 10 ; 10: 30: 50: 10$ respectively. The above powders were subsequently mixed and homogenized by hand for $30 \mathrm{~min}$ in an agate mortar. Finally, they were loaded on to the holder for XRD measurement. Those mixtures were prepared and then underwent XRD tests by triplicate, but XRD patterns didn't show significant differences. Inner standard substance has been added in each powder to control the crystal lattice parameters. This operation allowed observing wide range of silicate isomorphic substitutions that was especially useful for olivine.

\section{Processing and results}

Almost all the analyzed samples show similar mineralogical composition decides the samples directly from the lava from, which compose kaersutite. The most complicated analytical peak was (130) by Ol. The low quantity of Ol, the peak overloading by fluctuation of dhkl from 2.7991 to $2.7700 \AA$ needs special conditions (Fig. 2).

To find out the reasons for the peak profile transformations, we analyzed the olivine composition by X-ray and XRMA data (Table 1).

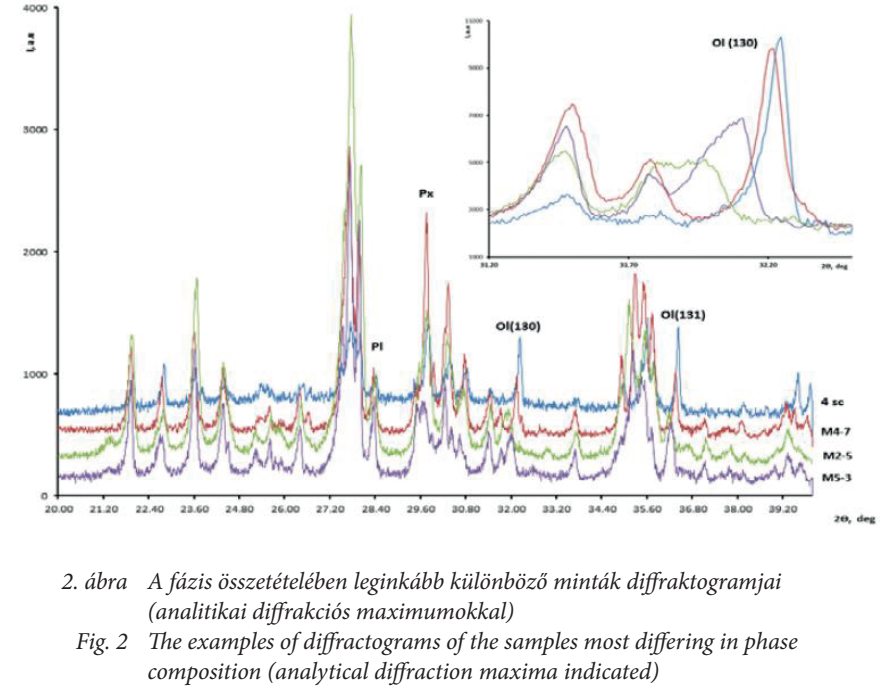

\begin{tabular}{|c|c|c|c|}
\hline \multirow[t]{2}{*}{ Sample } & \multirow[t]{2}{*}{$\begin{array}{l}\text { Fo\% (XRD } \\
\text { average) }\end{array}$} & \multicolumn{2}{|c|}{$\begin{array}{c}\text { Fo } \%(\text { XRMA) center of crystal/ } \\
\text { rim of crystal }\end{array}$} \\
\hline & & size $>700 \mu \mathrm{m}$ & Size $<700 \mu \mathrm{m}$ \\
\hline $4 s c$ & 89 & $89 / 90 / 82$ & $77 / 87$ \\
\hline 4B & 86.5 & $89 / 81$ & $83 / 81$ \\
\hline $4-9$ & 85 & $88 / 77$ & $83 / 81$ \\
\hline $4-6$ & 80 & $89 / 81$ & $88 / 77$ \\
\hline $4-7$ & 78 & $90 / 93 / 81$ & $83 / 77$ \\
\hline $6 N B$ & 87 & $89 / 81$ & $88 / 77$ \\
\hline $6 N-B s c$ & 79 & $89 / 79$ & 77 \\
\hline 6SB-liq & 73 & 77 & $77 / 69$ \\
\hline 6SB1 & 73 & $75 / 67$ & 71 \\
\hline 6SB2 & 71 & 75 & 71 \\
\hline M2-5 & 49 & 49 & $50 / 49$ \\
\hline M1-8 & 72 & $73 / 67$ & 72 \\
\hline M19-12-liq & 72 & $71 / 73 / 67$ & $70 / 67$ \\
\hline M25-02liq & 73 & - & $72 / 69$ \\
\hline M5-3 & 68 & 73 & 67 \\
\hline p1-1 & 70 & $79 / 73$ & $78 / 67$ \\
\hline p2 & 72 & - & $73 / 70$ \\
\hline p3a & 73 & & \\
\hline p4 & 77 & $79 / 78$ & $81 / 72$ \\
\hline p6 & 75 & $81 / 76$ & $80 / 72$ \\
\hline p5 & 71 & 78 & $79 / 72$ \\
\hline
\end{tabular}

1. táblázat Ol-ben az XRD és XRMA módszerrel mért Fo\% összehasonlitása Table 1 Comparing Fo\% in Ol measuring by XRD and XRMA

For examples BSE (COMPO) images of olivine crystals from the early melt crystallization appear to have a normal zoning pattern that shows dark cores surrounded by bright rims, implying that Fe increases towards the rim. However, the higher resolution images show that between the cores and the rims there is a zone of higher Fo and $\mathrm{Ni}$ content. The main mechanism of the $\mathrm{Pl}$ and $\mathrm{Cpx}$ crystals growth is agglomeration from nano-and/ or micro-particles. The sizes of these aggregates are from $0, \mathrm{~N}$ $\mathrm{mkm}$ to $\mathrm{N} \mathrm{mm}$. When the lava spreads over a larger distance $(\mathrm{km})$, the redox conditions destroy the olivine structure and produce the micro inclusions of $\mathrm{Px}+\mathrm{Mgt}$. All of these processes 
(Fig. 3) lead to broadening of the diffraction maxima. This can result in difficulties when correcting the intensity measurements. It is therefore necessary to use more reliable combination of calibration from mixtures of monomineral phases and control of the degree of heterogeneity from SEM images

The XRD semi-quantitative analytic results are presented in Fig. 4. Some of the important phase-ratios are calculated. The phase behaviour according to optical and X-ray data differ, especially in the case of growth by agglomeration with down density (gaps between crystallites may be up to 50\%).

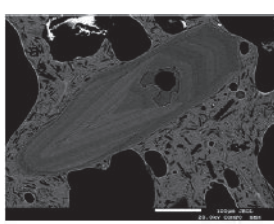

$4 \mathrm{sc}$

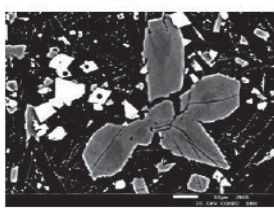

$\mathrm{M} 2-5$

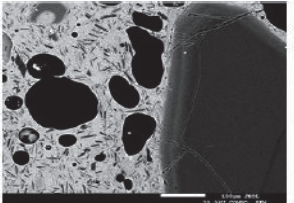

$4 \mathrm{sc}$

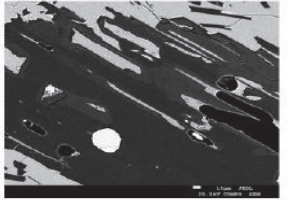

M5-3

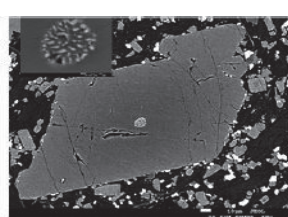

4-7

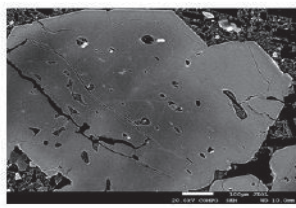

P4
3. ábra A SEM-képek a bazaltok és ásványok különbözőségéröl, heterogenitásáról Fig. 3 The SEM images in composition contrast showing heterogeneity of basalts and minerals

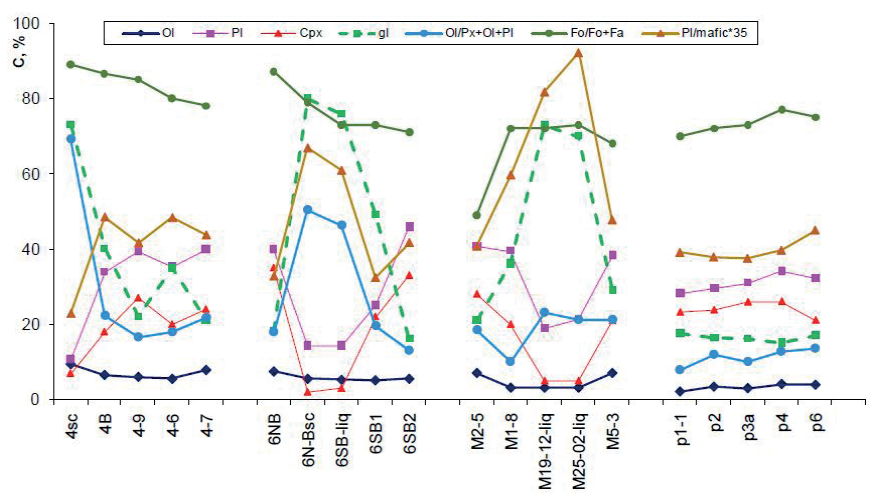

4. ábra A szilikát ásványi anyagok tartalmának, arányuknak és az Mg-tartalomnak az Ol-ben történő számszerüsitése

Fig. 4 Quantification of the silicate minerals content, their ratios and the $\mathrm{Mg}$-content in $\mathrm{Ol}$

\section{Conclusions}

On the basis of a comparison of the phase composition of these samples, we clarify the transformation of the mineral phases due to crystallization and/or dissolution, as well as the diffusion of the components in the final stage of rock crystallization. The main observable patterns are:

1) A decrease in the amount of olivine in front of lava flow which is attributable to redox conditions

2) The similarity in phase composition and the relative stability of the phase ratios, while the magnesian differences are sensitive to the cooling conditions: temperature, spreading rate and quenching rate.

3) A direct correlation between the crystallinity of the samples and the content of plagioclase and clinopyroxene. The mass crystallization of clinopyroxene, titanomagnetite, plagioclase occurs during the outflow of lava to the surface, appearance kaersutite in front of lava flow
4) Increasing content of Fe in olivines in some of lava flows along with small oscillations/fluctuation of the common olivine content in basalt.

When the ratios of the mineral phases are calculated according to the optical method it is impossible to take into account the real microstructure. Development work is required to study every basaltic series, but testing showed that the correct mineral ratios are achieved by XRD- means. The usefulness of this approach is to reduce the data processing time and amount of errors by petrological calculations in the routine rock study in microscope.

\section{References}

[1] Kotova, O. B. - Shushkov, D. A. - Gömze, L. A. - Kurovics, E. - Ignatiev, G. V. - Sitnikov, P. A. - Ryabkov, Y. I. - Vaseneva, I. N.: Composite materials based on zeolite-montmorillonite rocks and aluminosilicate wastes Építőanyag - JSBCM, Vol. 71, No. 4 (2019), 125-130. p. https://doi.org/10.14382/epitoanyag-jsbcm.2019.22

[2] Razmyslov, I. N. - Kotova, O. B. - Silaev, V. I. - Rostovtsev, V. I. Kiseleva, D. V. - Kondrat'ev, S. A.: Microphase Heterogenization of High-Iron Bauxite as a Result of Thermal Radiation, Journal of Mining Science, Vol. 55. No. 5 (2019) 811-823 p. https://ink.springer.com/content/pdf/10.1134/S1062739119056185.pdf

[3] Kurovics, Emese - Kotova, Olga B. - Gömze, László A .- Shushkov, Dmitry A. - Ignatiev, Grigoriy V. - Sitnikov, Petr A. - Ryabkov, Yuri I. - Vaseneva, Irina N. - Gömze, Ludmila N.: Preparation of particlereinforced mullite composite ceramic materials using kaolin and IG-017 bio-origin additives Építőanyag - JSBCM, Vol. 71, No. 4 (2019), 114-119. p. https://doi.org/10.14382/epitoanyag-jsbcm.2019.20

[4] Kotova, O et al 2018 Proceedings of the 10th Edition of Euroinvent European exhibition of creativity and innovation. Euroinvent . 10-31 Mai 2018 “George Enescu”, Iasi, Romania 550. p.

[5] Ponaryadov, A. - Kotova, O.: Phosphate sorption on leucoxene, Vestnik of Geosciences No. 1 (2020) 19-23. p. https://doi.org/10.19110/geov.2020.1.3

[6] Tatlock, D. B.: Rapid modal analysis of some felsic rocks from calibrated X-ray diffraction patterns: U.S. Geol. Survey Bull. 1209 (1966) 41. p.

[7] Andrews, J. T. - Kristjansdottir, G. B. - Eberl, D. D. - Jennings, A.: A quantitative X-ray diffraction inventory of the tephra and volcanic glass inputs into the Holocene marine sediment archives off Iceland: A contribution to V.A.S.T., Polar Research, Vol. 32. (2013) https://doi.org/10.3402/polar.v32i0.11130

[8] Wadsworth, W. B. - Baird, A. K.: Modal analysis of granitic rocks by X-ray diffraction, Canadian Mineralogist Vol. 27 (1989) 323-341. p. https://pdfs.semanticscholar.org/4891/94475f823737a1cbba85a4d77b51f2537048.pdf

[9] Zhao, P. - Lu, L. - Liu, X. - De la Torre, A.G. - Cheng, X.: Error Analysis and Correction for Quantitative Phase Analysis Based on RietveldInternal Standard Method: Whether the Minor Phases Can Be Ignored? Crystals Vol. 8 No. 3. (2018) 110. p. https://doi.org/10.3390/cryst8030110

[10] Piip, B.I., 1946. A new flank crater on Plosky Tolbachik Volcano. Bull. Vol. Obs. Kamchatka Vol. 13 (1946) 10-21. p.

[11] Fedotov, S.A.: The 1975-1976 Large Tolbachik Fissure Eruption in Kamchatka, Moscow, Nauka, (1984) 637.p.

[12] Churikova, T. G. - Gordeychik, B. N. - Iwamori, H. - Nakamura, H. Ishizuka, O. - Nishizawa, T. - Haraguchi, T. - Miyazaki, T. - Vaglarov, B. S.: Petrological and geochemical evolution of the Tolbachik volcanic massif, Kamchatka, Russia, J. of Volcanology and Geothermal Research Vol. 307 No. 1 (2015) 156-181. p. https://doi.org/10.1016/j.jvolgeores.2015.10.026

[13] Corsaro, R.A. - Miraglia, L. - Pompilio, M.: Petrologic evidence of a complex plumbing system feeding the July-August 2001 eruption of Mt. Etna, Sicily, Italy. Bull Volcanol Vol. 69. (2007) 401-421.p. https://doi.org/10.1007/s00445-006-0083-4

Ref.:

Gembitskaya, Irina M. - Kotova, Elena L. - Abdrakhmanov, Ilnur A. - Kurovics, Emese - Gömze, László A.: Insights into the applicability of the X-Ray phase quantification supported by SEM for the rock-forming silicates minerals in the basaltic lava flows Építöanyag - Journal of Silicate Based and Composite Materials, Vol. 72, No. 5 (2020), 174-177. p. https://doi.org/10.14382/epitoanyag-jsbcm.2020.29 